\title{
Safety and effectiveness of recombinant human growth hormone replacement in postoperative craniopharyngioma children
}

\author{
Zhang-qian Zheng ${ }^{*}$, Di-jing Zhi, Shui-xian Shen, Fei-hong Luo, Zhu-hui Zhao, Zhong Lu, Rong Ye, Ruo-qian Cheng, \\ Xiao-jing Li
}

From 7th APPES Biennial Scientific Meeting

Nusa Dua, Bali. 14-17 November 2012

\section{Aims}

To observe the safety and effectiveness of recombinant human growth hormone (rhGH) replacement therapy (GHRT) in postoperative craniopharyngioma (CP) children.

\section{Subjects and methods}

We reviewed the records for all patients undergoing GHRT at our hospital over the study period. Patients were included if they had received CP resection, GHRT for at least 12 months, and records of serial magnetic resonance imaging data and data for treatment, pituitary hormone profiles and growth chart were available. GHnaïve control patients were selected from our hospital database of patients carried out the same surgery. Patients were matched for date of surgery, age, site of primary diagnosis and sex.

\section{Results}

18 patients were recruited with growth hormone deficiency. In treatment group, all patients all gained acceleration in growth velocity and elevated growth factors level. There were no recurrent tumors found in both groups.

\section{Conclusions}

Our study demonstrates no increased risk for recurrent in patients receiving GHRT, thus supporting a high safety profile of GHRT in postoperative craniopharyngioma children. Additionally, GHRT can provide a

Department of Endocrinology and Inherited metabolic disease, Children's Hospital of Fudan University, Shanghai, 201102, China significantly change in growth velocity compared with control group.

Published: 3 October 2013

doi:10.1186/1687-9856-2013-S1-P63

Cite this article as: Zheng et al:: Safety and effectiveness of recombinant human growth hormone replacement in postoperative craniopharyngioma children. International Journal of Pediatric Endocrinology 2013 2013(Suppl 1):P63.
Submit your next manuscript to BioMed Central and take full advantage of:

- Convenient online submission

- Thorough peer review

- No space constraints or color figure charges

- Immediate publication on acceptance

- Inclusion in PubMed, CAS, Scopus and Google Scholar

- Research which is freely available for redistribution
C Biomed Central 